\title{
Embelin: an HPTLC method for quantitative estimation in five species of genus Embelia Burm. f.
}

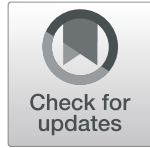

\author{
K. P. Rini Vijayan and A. V. Raghu * (]
}

\begin{abstract}
Background: The plants belonging to the genus Embelia, a significant tropical genus with many biological activities, are benefiting because of their robust medicinal properties. Embelin is one of the principal bioactive molecules responsible for the medicinal properties of the genus Embelia. The quantification of the embelin compound among different species in this genus has not yet been investigated, so still uncertain which species and which part should be accepted. The present study was intended to establish a speedy and precise highperformance thin-layer chromatographic (HPTLC) method for quantitative study of embelin in various plant parts of Embelia ribes, Embelia tsjeriam-cottam, Embelia basaal, Embelia adnata, and Embelia gardneriana.

Result: This research confirmed the method as per the International Conference on Harmonization (ICH) guidelines. We achieved separation on silica gel 60 F254 HPTLC plates using propanol: butanol: ammonia (7:3:7 v/v/v) as a mobile phase. Densitometry scanning performed for detection and quantification at $254 \mathrm{~nm}$ and $366 \mathrm{~nm}$. Among the species investigated, the highest amount of embelin was found in E. ribes fruits.

Conclusion: Embelia ribes fruits are the best source of embelin. Embelin was first described in the endemic species, such as E. adnata and E. gardneriana. The method illustrated in this research may be applied for quantification of embelin and fingerprint analysis of other species within Embelia genus or described genera and chemo taxonomic studies of this genus.
\end{abstract}

Keywords: Embelin, HPTLC, Embelia ribes, Embelia tsjeriam-cottam, Embelia adnata, Embelia gardneriana

\section{Background}

The genus Embelia (fam Primulaceae) offers a considerable position among the pharmaceutical field as a number of medicinal properties have been noted. The species under this genus are commonly used in the traditional practices of medicines like Ayurveda, Chinese medicine, and Siddha for a number of decades. In Ayurveda, dried berries of this genus is noted as "vidanga" which carry various biological activities like anthelmintic, carminative, antibacterial, antibiotic, and hypoglycemic properties and is an ingredient in about 75 traditional Ayurvedic drug formulations $[1,2]$. New studies revealed

* Correspondence: dravraghu@gmail.com

KSCSTE-Kerala Forest Research Institute, Peechi, Kerala 680653, India the medicinal potential of this genus by reporting biological properties, like hepatoprotective, analgesic, amylase inhibitory, trypsin inhibition, antibacterial, anticonvulsant, adaptogenic, antifertility, anticancer, antihyperlipidemic, antifungal [3], anti-diabetic [4], antimicrobial [5], antioxidant, and $\alpha$-glucosidase inhibitory activities [6]. Variety of medicinal properties implies the presence of different potent effective compounds of this genus [6-13].

Embelin (2,5 dihydroxy-3-undecyl-1,4 benzoquinone) (Fig. 1) is a significant active compound present in this genus. Pharmacotherapeutics of embelin are neurodegenerative disorders, hepatoprotective, anthelminthic, anti-inflammatory, nanomedicine, antioxidant, antimitotic, radio protective, anticancer, respiratory disorders, 


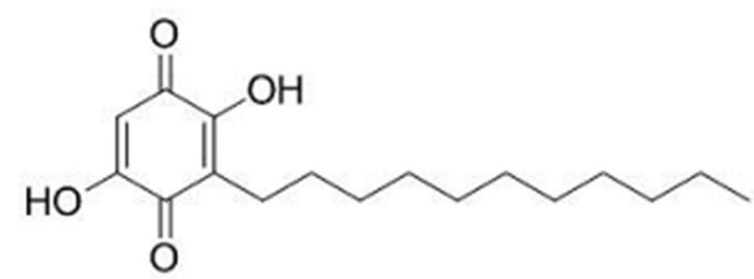

Fig. 1 Structure of embelin

contraceptive, antispermatogenic, anti-infective, antihyperlipidemic, antihyperglycemic, analgesic, antipyretic, gastrointestinal disorders, and wound healing activity [14-17]. The presence of embelin was published in many species of Embelia in its fruits, but from the other parts is very minimal. Quantification of embelin from the different parts as well as different species of the Embelia is very important, since the new source of this important compound should be identified and explored. The objective of this work was, hence, to determine a simple, solid, cost effective, and rapid HPTLC method for quantification of embelin in different parts of Embelia ribes, E. tsjeriam-cottam, E. basaal, E. adnata, and E. gardneriana. Marker compounds are being employed for evaluation, standardization, and characterization of medicinal plants [18], and HPTLC is generally accepted applied analytical technique for this [19-21]. The developed method was verified as per the International Conference on Harmonization (ICH) guidelines [22].

\section{Method}

\section{Plant material collection}

We collected the plant parts of different species of Embelia for the study from different wild regions of Kerala and Tamil Nadu states of India (Table 1) with approval solicited from the Forest Department. The material was identified and verified by Dr. Udayan P. S., Head, Department of Botany and Research Centre, Sreekrishna College, Kerala, India, and deposited at CALI herbarium. Based on our previous experience in similar studies, the best season for collection of plants material for phytochemical studies is spring/summer season, so samples were collected during the months of February and March. Collected samples were separated into distinct parts, such as stem, leaves, and bark. In all the species except E. basaal, roots were exempted from the collection because of the limited population. The samples were washed in running tap water, followed by double distilled water and dried at room temperature $\left(28-33{ }^{\circ} \mathrm{C}\right)$. We kept the powdered dry samples in airtight bottles at room temperature until analysis.

\section{Preparation of sample}

Different parts like leaf, stem, bark, root, and fruits of the selected species were shade dried and pulverized. We extracted $10 \mathrm{~g}$ each sample in $100 \mathrm{ml}$ of $\mathrm{n}$-Hexane for $6 \mathrm{~h}$ in a soxhlet apparatus. Extracts were concentrated by evaporating the solvent and dissolved in methanol $(10 \mathrm{ml})$ and exposed to different analyses for the detection and further quantification of embelin.

\section{Chemicals}

All the solvents used for the study were of analytical grade and were procured from Merck (Mumbai, India). The standard embelin was purchased from SigmaAldrich, St. Louis, MO, USA.

\section{Chemical method}

For the qualitative description of embelin, the extract was dissolved in petroleum ether and diluted ammonia solution was added to it. Formation of bluish violet precipitate shows the presence of embelin.

\section{Development of optimum mobile phase}

For the development of optimum mobile phase, the standard embelin was dissolved in methanol and loaded on an activated pre-coated TLC plate using a capillary tube and was allowed to develop in TLC chamber saturated with various mobile phases with various combinations and concentrations of solvents.

\section{Preparation of stock solution}

The stock solution of standard embelin $(1 \mathrm{mg} / \mathrm{ml})$ was drawn up by dissolving $10 \mathrm{mg}$ of embelin standard in 10 $\mathrm{ml}$ of methanol. From the stock solution, using standard solution of embelin was prepared by further dilution of $1 \mathrm{ml}$ of ready solution into $10 \mathrm{ml}$ with methanol (100 $\mu \mathrm{g} / \mathrm{ml})$. For quantification purpose, various volumes of stock solution $(1,2,3,4,5 \mu \mathrm{l})$ were spotted on the TLC plate along with sample solution.

Table 1 Collection details of different species of Embelia

\begin{tabular}{llll}
\hline Sl. no. & Species name & Locality & Voucher specimen no. \\
\hline 1 & Embelia basaal & Idukki, Kerala & $17691,17692,17693,17694$ \\
2 & Embelia adnata & Mathikettan Shola National Park, Idukki, Kerala & 17695,17696 \\
3 & Embelia gardneriana & Sisparah, Silent Valley, Kerala & 17690 \\
4 & Embelia ribes & Valparai, Tamilnadu & 5795 \\
5 & Embelia tsjeriam-cottam & Thrissur, Kerala & 5176 \\
\hline
\end{tabular}




\section{Chromatographic instruments and conditions}

A CAMAG automatic TLC sampler 4 (CAMAG, Muttenz, Switzerland) and a CAMAG $25 \mu \mathrm{l}$ sample syringe with CAMAG ATS 4 applicator were used for sample application. Pre-coated silica gel 60 F254 HPTLC plates (E. Merck, Darmstadt, Germany) of $0.2 \mathrm{~mm}$ thickness was used as the stationary phase. After the spotting of samples, the plates were developed in a twin trough chamber pre saturated with mobile phase and run to solvent front $90 \mathrm{~mm}$ under room temperature. Photographs of the developed plates were performed employing a CAMAG TLC visualizer at $254 \mathrm{~nm}$ and $366 \mathrm{~nm}$. Densitometry scanning of the developed plates were performed using CAMAG TLC scanner in $366 \mathrm{~nm}$ and 254 $\mathrm{nm}$ with a slit dimension of $6 \times 0.30 \mathrm{~mm}$ and better quantification, and data analysis was worked out by the CAMAG winCATS integrated software.

\section{Preparation of calibration curve of embelin and quantification of embelin}

Samples and the standard embelin were spotted on a pre-coated and activated silica plates. The different concentration of embelin (1-5 $\mu \mathrm{l})$ corresponding to 100 , $200,300,400$, and $500 \mathrm{ng}$ embelin were employed on the plates along with samples with a bandwidth of $8 \mathrm{~mm}$ and a distance between tracks of $13.5 \mathrm{~mm}$. Before the development of the plates, the chamber was saturated with the mobile phase. Then the plates were developed to a height of $9 \mathrm{~cm}$ at room temperature. After development, the plates were dried under air current. The photographs of the plates were taken and scanning was performed under $366 \mathrm{~nm}$ and $254 \mathrm{~nm}$. The peak areas were noted and the calibration curve was plotted with concentration vs peak areas (Fig. 2).

\section{Results \\ Optimization of HPTLC separation}

The optimal mobile phase used for the effective identification and quantification of embelin was propanol:butanol: ammonia in 7:3: $7 \mathrm{v} / \mathrm{v} / \mathrm{v}$. This combination resulted in formation of an intact band specifically for embelin (Figs. 3, $4,5,6$, and 7). The bands were visible with a pink coloration. The $\mathrm{Rf}$ value was calculated as 0.6. The standard compound was too scanned, and its spectrum was recorded in the range of 100 to $800 \mathrm{ng}$. The HPTLC chromatogram of standard embelin is presented in Fig. 8. Of all the 18 investigated samples, except leaves showed a positive result for the presence of embelin. The concentration of embelin in different extracts varied significantly between samples. The proposed HPTLC method was validated in terms of linearity, precision, accuracy, LOD, and LOQ. The summary of the HPTLC validation parameters and $\mathrm{Rf}$ value was given in Table 2 .

\section{Quantification of embelin in different extracts}

The results of the quantification of embelin in different samples studied are presented in Table 3. From the details of the quantification study, it can be noticed that











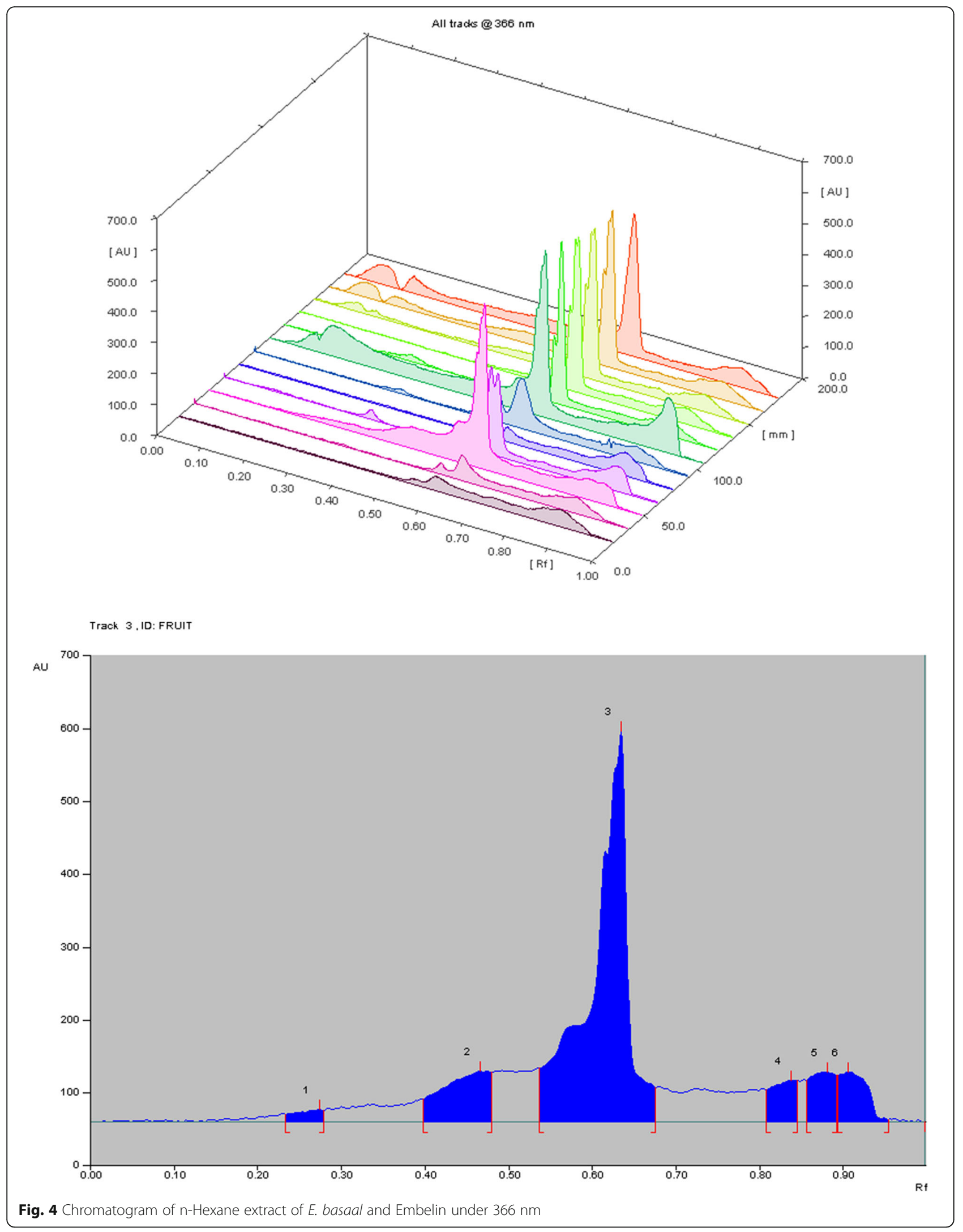




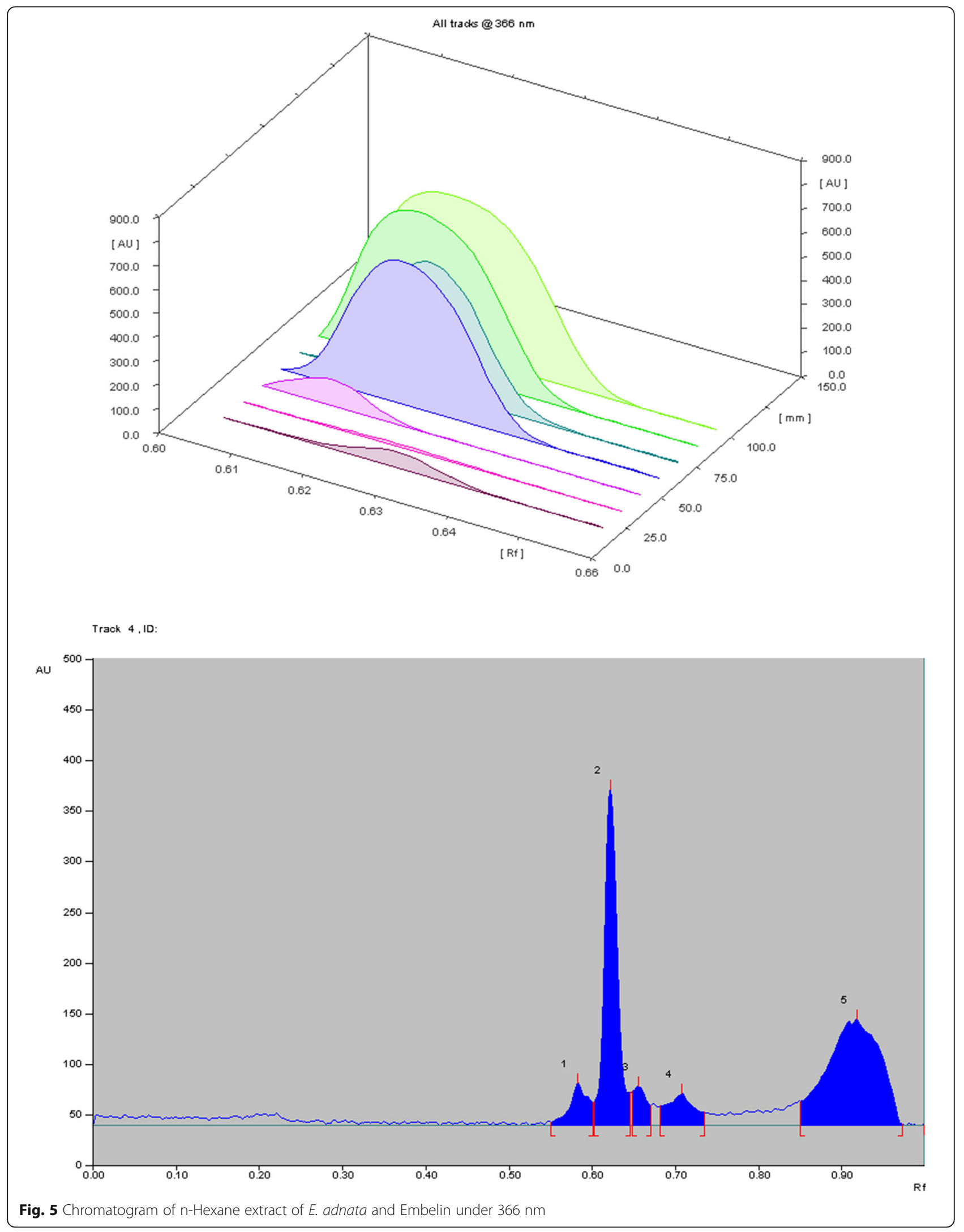




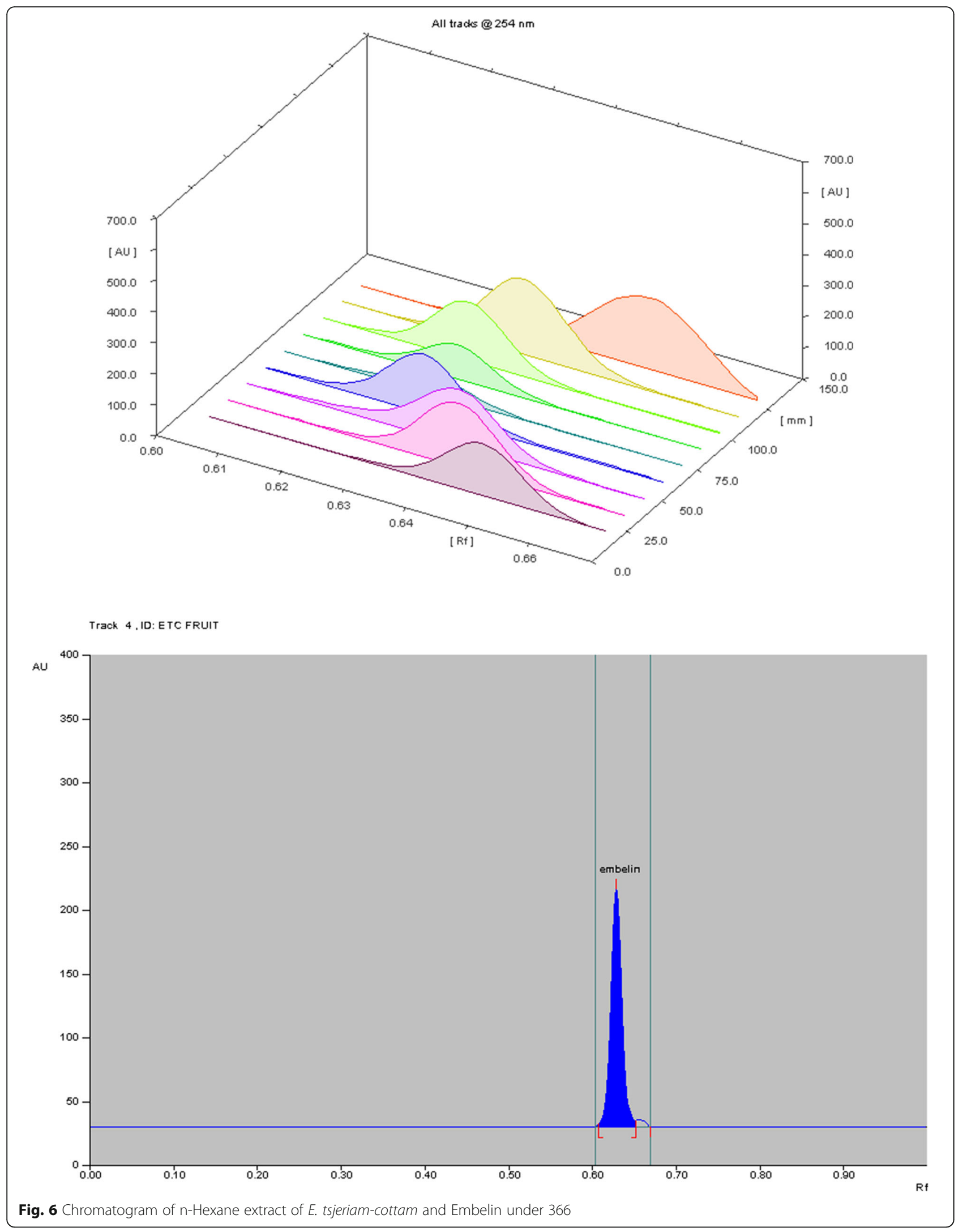




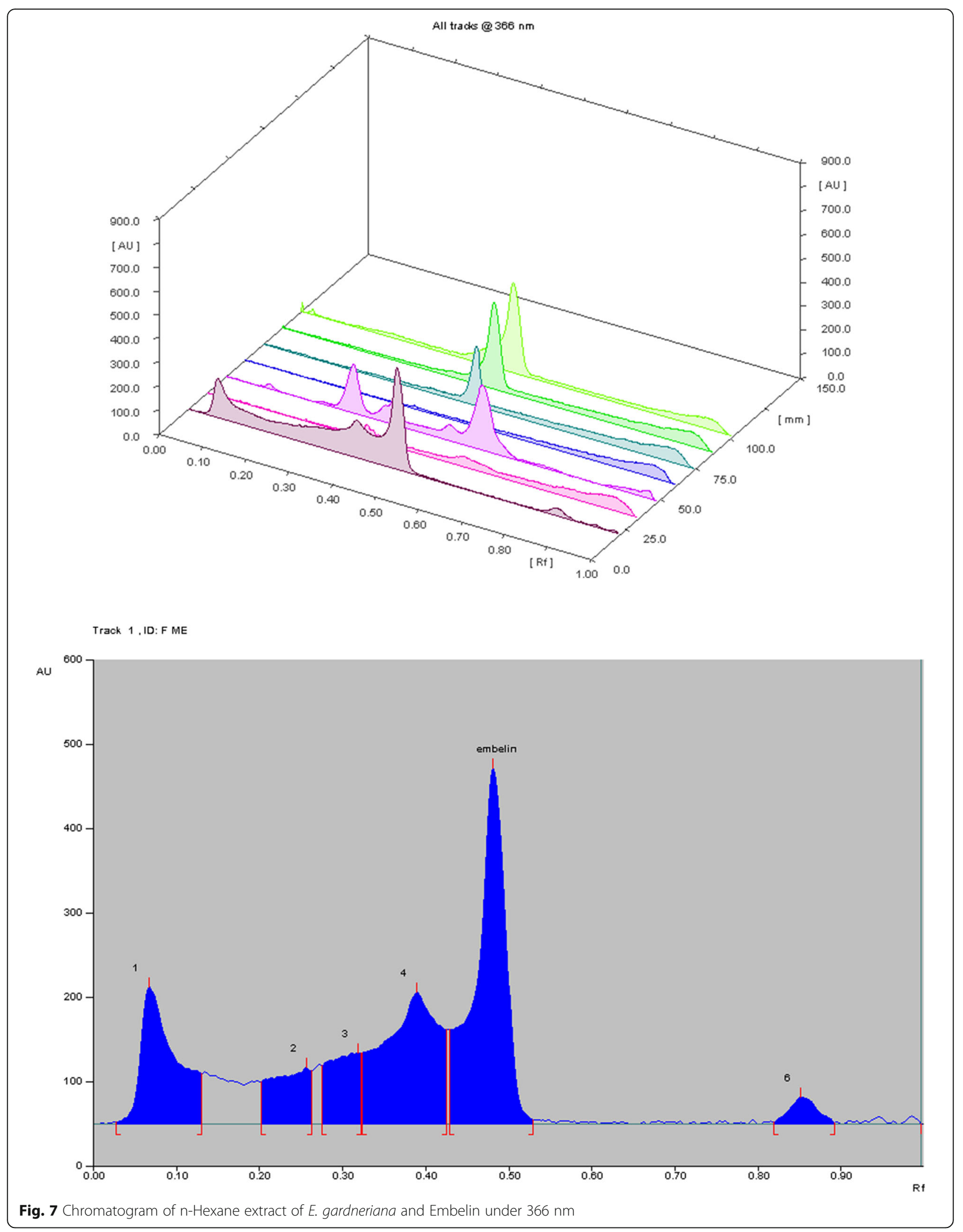


Track 7.10



Fig. 8 HPTLC chromatogram of standard embelin at $366 \mathrm{~nm}$

the embelin concentration from different samples ranges from 100 to $900 \mathrm{ppm}$. The concentration of embelin showed considerable variation among samples. The highest concentration of embelin was established in fruits of $E$. ribes which was followed by E. basaal fruits. The lowest concentration was reported in E. gardneriana fruits. In all other samples, including stem and bark, even though the presence of the compound was noted, the quantification was challenging due to the very low concentration. It is a very important discovery that the embelin is not detected in the leaves of species we studied.

\section{Discussion}

Nowadays, phytochemicals have been receiving recognition and are belonging to an important part of drug design. So identification and quantification of promising compounds from plants have significant value in research. Embelin (2,5-dihydroxy-3-undecyl-1,4-benzoquinone) is an alkyl substituted hydroxy quinone isolated from numerous medicinal plants chiefly from

Table 2 Rf value and linear regression data for HPTLC analysis of embelin

\begin{tabular}{ll}
\hline Linearity range $(\mathbf{n g})$ & $\mathbf{1 0 0 - 5 0 0} \mathbf{n g}$ \\
\hline Regression equation & $7497.524+3.206 x$ \\
Correlation coefficient $\left(\boldsymbol{r}^{\mathbf{2}}\right)$ & 0.8118 \\
LOD $\left(\mathrm{ng} \mathrm{band} \mathbf{b}^{-1}\right)$ & $98 \mathrm{ng}$ per band \\
LOQ $\left(\mathrm{ng} \mathrm{band} \mathrm{b}^{-1}\right)$ & $323 \mathrm{ng}$ per band \\
Rf & 0.6 \\
\hline
\end{tabular}

the genus Embelia and have various medicinal properties $[14,23]$. There are several papers available for the quantification of embelin in different Embelia species. Most of the studies were restricted to E. ribes and E. tsjeriamcottam [24-26]. A good mobile phase equally plays an absolutely vital part in chromatographic methods. As much as assessment of embelin by chromatographic methods is concerned, hardly a few number of HPTLC solvent systems have been described [24, 27]. In our research, HPTLC method was developed with a view in developing an assay method for simultaneous estimation of embelin in a single solvent system. The mobile phase consisting mixture of propanol: butanol: ammonia (7: 3: $7 \mathrm{v} / \mathrm{v} / \mathrm{v})$ produced sharp and symmetrical peaks with the $\mathrm{Rf}$ value of 0.6. The limit of determination (LOD) is refering to the smallest amount or concentration of an analyte that can be detected but not necessarily quantitated as an exact value $[28,29]$, whereas the LOQ is referring to the lowest amount of analyte in a sample which can be quantitatively determined with suitable precision and accuracy. The quantitation limit is a parameter of quantitative assays for low levels of compounds in sample matrices and is used principally for the determination of impurities and or degradation products [28]. Moreover, it is the indicator of the extraction [29]. The calculated LOD and LOQ in this investigation were identified to be inadequate, and this implies the sensitivity of the method.

The quantification and comparison of embelin within the species of Embelia have considerable importance. As well as it is too important to notice out new plant sources of the embelin and to identify in which plant 
Table 3 Estimation of embelin in different Embelia species

\begin{tabular}{|c|c|c|c|c|}
\hline Species & Parts used & Quantity of extract & Peak area & Embelin content \\
\hline \multirow[t]{4}{*}{ Embelia ribes } & Bark & $5.0 \mu \mathrm{l}$ & Out of permitted range & Not quantifiable \\
\hline & Leaf & $5.0 \mu \mathrm{l}$ & Not detected & \\
\hline & Fruit & $5.0 \mu \mathrm{l}$ & 1946.78 & 0.09\%/900 ppm \\
\hline & Stem & $10.0 \mu \mathrm{l}$ & Out of permitted range & Not quantifiable \\
\hline \multirow[t]{4}{*}{ Embelia tsjeriam-cottam } & Bark & $5.0 \mu \mathrm{l}$ & Out of permitted range & Not quantifiable \\
\hline & Leaf & $5.0 \mu \mathrm{l}$ & Not detected & \\
\hline & Fruit & $5.0 \mu \mathrm{l}$ & 6449.61 & 0.0133\%/133 ppm \\
\hline & Stem & $10.0 \mu \mathrm{l}$ & Out of permitted range & Not quantifiable \\
\hline \multirow[t]{4}{*}{ Embelia basaal } & Bark & $5.0 \mu \mathrm{l}$ & Not detected & \\
\hline & Leaf & $5.0 \mu \mathrm{l}$ & Out of permitted range & Not quantifiable \\
\hline & Fruit & $5.0 \mu \mathrm{l}$ & 9163.20 & $0.06 \%$ / 600 ppm \\
\hline & Stem & $10.0 \mu \mathrm{l}$ & 837.07 & Not quantifiable \\
\hline \multirow[t]{3}{*}{ Embelia adnata } & Stem & $5.0 \mu \mathrm{l}$ & Out of permitted range & Not quantifiable \\
\hline & Leaf & $5.0 \mu \mathrm{l}$ & Not detected & \\
\hline & Fruit & $5.0 \mu \mathrm{l}$ & 8864.42 & $0.0213 \% / 213$ ppm \\
\hline \multirow[t]{3}{*}{ Embelia gardneriana } & Stem & $5.0 \mu \mathrm{l}$ & Out of permitted range & Not quantifiable \\
\hline & Leaf & $5.0 \mu \mathrm{l}$ & Not detected & \\
\hline & Fruit & $5.0 \mu \mathrm{l}$ & 9196.55 & $0.01 \% / 100 \mathrm{ppm}$ \\
\hline
\end{tabular}

part have this compound in excess. Fruits are the major source of embelin in all the species studied.

\section{Conclusion}

We have established an HPTLC method for the study of the embelin content in different morphological parts of five Embelia species. The method followed in the research was confirmed for linearity, precision, accuracy, limit of detection and quantification, and specificity by ICH guidelines. This method may be adopted for quantification of embelin and fingerprint study of alternative species within Embelia genus or associated genera. Total embelin content was quantified by the developed method and compared in different plant parts of five species for the first time. This research identified embelin in all the species investigated. The study reported the presence of embelin in two endemic species of Western Ghats. The results establish with new findings suggesting embelin may be chemo taxonomic marker of this genus.

\section{Abbreviations}

HPTLC: High performance thin layer chromatography; ICH: International Council for Harmonisation; TLC: Thin layer chromatography; LOD: Limit of detection; LOQ: Limit of quantification; Rf: Retention factor

\section{Acknowledgements}

The authors gratefully acknowledge Dr. C.T. Sulaiman, Senior Scientist, Phytochemistry Division, Center for Medicinal Plants Research (CMPR), AVS, Kottakkal, Kerala, India, for his critical comments on the manuscript. The help rendered by Dr. P.S. Udayan, Professor in Botany, Sreekrishna College, Guruvayur, Kerala, India, in collection and identification of the plant species are acknowledged with praise. We also thank Dr. Indira Balachandran, Director, CMPR for granting facilities for quantification studies.
Encouragement and support offered by Dr. SyamViswanath, Director, KSCS TE-KFRI, Peechi, Kerala, and financial support extended by KSCSTE are gratefully acknowledged.

\section{Plant authentication}

Botanical authentication of the plant parts was carried out at the Department of Botany and Research Centre, Sreekrishna College, Kerala, India, by Dr. P. S. Udayan where voucher specimens of plants have been deposited in the CALI (University of Calicut) herbarium.

\section{Authors' contributions}

All authors have read and approved the manuscript. AVR designed and executed the work. RVKP performed experimental works and data compilation.

\section{Funding}

The entire study was financially supported by the plan funded by KSCSTEKFRI.

\section{Availability of data and materials}

The data used to support the findings of this study are available from the corresponding author upon request.

Ethics approval and consent to participate

Not applicable. This research article does not contain any studies using animals or human.

\section{Consent for publication}

Not applicable.

Competing interests

The authors declare that they have no competing interests. 
Received: 15 December 2020 Accepted: 14 February 2021

Published online: 25 February 2021

\section{References}

1. Anonymous (2002) The wealth of India: a dictionary of Indian raw materials and industrial products - raw materials series. Publications and Information Directorate, CSIR, New Delhi 3:74-75

2. Sivarajan W, Balachandran I (1994) Ayurvedic drugs and their plant sources. Oxford and IBH Publishing Co Pvt Ltd, India:267-269

3. Souravi K, Rajasekharan PE (2014) A review on the pharmacology of Embelia ribes burm.f.-a threatened medicinal plant. Int J Pharm Bio Sci 5(2):443-456

4. Durg S, Veerapur VP, Neelima S, Dhadde SB (2017) Antidiabetic activity of Embelia ribes, embelin and its derivatives: a systematic review and metaanalysis. Biomed Pharmacother 86:195-204

5. Dhayalan M, Denison MIJ, Krishnan K (2017) In vitro antioxidant, antimicrobial, cytotoxic potential of gold and silver nanoparticles prepared using Embelia ribes. Nat Prod Res 31(4):465-468

6. Qin Y, Chen JP, Li CY, Zhu LJ, Zhang X, Wang JH, Yao XS (2020) Flavonoid glycosides from the fruits of Embelia ribes and their anti-oxidant and $a-$ glucosidase inhibitory activities. J Asian Nat Prod Res:1-7

7. Hao K, Ali M, Siddiqui AW (2005) New compounds from the seeds of Embelia ribes Burm. Pharmazie 60(1):69-67

8. Manguro LOA, Ugi I, Lemmen P (2005) Flavonol glycosides from the leaves of Embelia keniensis. J Chinese Chem Soc 52(1):201-208

9. Lin P, Li S, Wang S, Yang Y, Shi J (2006) A nitrogen-containing 3-alkyl-1,4benzoquinone and a gomphilactone derivative from Embelia ribes. J Nat Prod 69(11):1629-1632

10. Dang PH, Nguyen HX, Nguyen NT, Le HNT, Nguyen M (2014) a-Glucosidase inhibitors from the stems of Embelia ribes. Phytother Res 28(11):1632-1636

11. Bouzeko ILT, Ndontsa BL, MbaNquekeu YM, Awouafack MD, Wong CP, SimoMpetga JD, Mbouangouere R, Tane P, Morita H (2019) A new alkylbenzoquinone from Embelia rowlandii Gilg. (Myrsinaceae). Nat Prod Res 33(13):1909-1915

12. RiniVijayan KP, Raghu AV (2019) Polyphenolic profiling of two Embelia spp. endemic to South Western Ghats of India by liquid chromatography coupled with tandem mass spectrometry analysis. Nat Prod Res 7:1-5. https://doi.org/10.1080/14786419.2019.1687475

13. RiniVijayan KP, Raghu AV (2019) Tentative characterization of phenolic compounds in three species of the genus Embelia by liquid chromatography coupled with mass spectrometry analysis. Spectrosc Lett 52(10):653-670

14. Poojari R (2014) Embelin-a drug of antiquity: shifting the paradigm towards modern medicine. Expert Opin Investig Drugs 23(3):427-444

15. Xu Y, Liu D, Hu J, Ding P, Chen M (2020) Hyaluronic acid-coated pH sensitive poly ( $\beta$-amino ester) nanoparticles for co-delivery of embelin and TRAIL plasmid for triple negative breast cancer treatment. Int J Pharm 573: 118637

16. Zhaojun S, Siyuan G, Min G, Rongchao J, Xiaole C, Xuetao X, Dongli L, Kun Z, Wen-Hua C (2020) Synthesis and biological activity of embelin and its derivatives: an overview. Mini Rev Med Chem 20(5):396-407

17. Shrimali H, Mandal UK, Nivsarkar M (2019) Fabrication and evaluation of a medicated hydrogel film with embelin from Embelia ribes for wound healing activity. Futur J Pharm Sci 5(1):12

18. Manual WHO (1998) Quality control methods for medicinal plant materials. World Health Organization, Geneva

19. Al-Yousef HM, Alhowiriny TA, Siddiqui NA (2019) Quantification of two biomarker compounds by a validated high-performance thin-layer chromatographic method from different extracts of Pluchea dioscoridis growing in Saudi Arabia. JPC-J Planar Chromat 32:243-249

20. Shukla PK, Misra A, Patra KK (2020) Study of metabolite variability in Plumbago zeylanica Linn. Collected from different localities of the Gangetic plains of India. JPC-J Planar Chromat 33:179-189

21. Balekundri A, Mannur V (2020) Quality control of the traditional herbs and herbal products: a review. Futur J Pharm Sci 6:67

22. ICH (1996) Guidelines on validation of analytical procedure - methodology, in: Proceedings of the International Conference on Harmonization, Geneva.

23. Othman SNN, Teng Lum P, Sekar M, Mazlan NA, Yusri PZS, Ghazali NF, Mohd Idi H, Azman S, Ismail M, Noor AAM (2020) Molecules of interest embelin - a review. Research J. Pharm. and Tech. 13(7):3485-3493
24. Saraf A, Srinivas KS, Chaturvedi A (2016) Validation of HPTLC method for quantification of embelin from Embelia ribes Burm. f. Int J Pharmacog Phytochem Res 8(9):1492-1496

25. Pandey AK, Ojha V (2011) Estimation of embelin in Embelia tsjeriam-cottam fruits by HPLC to standardize harvesting time. Indian J Pharm Sci 73(2):216

26. Raja SS, Unnikrishnan KP, Ravindran PN, Balachandran I (2005) Determination of embelin in Embelia ribes and Embelia tsjeriam-conttam by HPLC. Indian J Pharm Sci 67(6):734

27. Ansari MN, Bhandari U (2008) High performance thin layer chromatographic method for quantification of embelin from Embelia Ribes Burm fruits. Indian Drugs 45:908-910

28. ICH (1997) Guidance for industry, validation of analytical procedures: methodology. International Conference on Harmonisation, USA

29. Horwitz W (2002) AOAC guidelines for single laboratory validation of chemical methods for dietary supplements and botanicals. AOAC International, Gaithersburg, MD, USA, pp 12-19

\section{Publisher's Note}

Springer Nature remains neutral with regard to jurisdictional claims in published maps and institutional affiliations.

\section{Submit your manuscript to a SpringerOpen ${ }^{\circ}$ journal and benefit from:}

- Convenient online submission

- Rigorous peer review

- Open access: articles freely available online

- High visibility within the field

- Retaining the copyright to your article

Submit your next manuscript at $>$ springeropen.com 